\title{
Pseudomeningocele after Lumbar Discectomy
}

\author{
Sang Woo Kim, Soo Ho Cho \\ Department of Neurosurgery, \\ College of Medicine, Yeungnam University, Daegu, Korea
}

\section{-Abstract-}

We report a case of postlaminectomy pseudomeningocele which treated successfully by surgical removal with fat graft. A 23-year-old man complained of low back pain and right leg pain and a soft mass in the back at the site of the incision. Four months earlier, he had undergone surgery for herniated nucleus pulposus on L4-L5 segment and three times revision surgery for CSF leakage. A magnetic resonance imaging(MRI) study revealed a large cystic formation in the low back which communicated with a laminectomy site. At surgery, the pseudomeningocele was exposed subcutaneously and explored inside without further laminectomy. A dural tear was identified just around the nerve root with some suture materials and there was persistent CSF leaks. The dura was closed with interrupted sutures. Then we performed sandwich-typed fat graft with glue. Postoperatively, his leg pain was relieved completely and the wound was healed satisfactory without palpable back mass.

Key Words : Pseudomeningocele, Laminectomy, Dural tear, Sandwich fat graft.

Introduction

Cerebrospinal fluid leaks are relatively common complication following spinal surgery. It may result from excessive traction of the nerve roots, direct trauma, postlaminectomy residual bone spikes and improper sutures of dura defects. ${ }^{1)}$ Leakage may occur at the suture line postoperatively. The dural tears may be occurred during extradural spinal approaches for disc surgery or decompressive laminectomy. The incidence of unintended durotomy during spinal surgery varies in different series between $4 \%$ and $14 \% .^{2-4)}$ Pseudomeningocele is defined as extradural collections of CSF that extravasate through

책임저자 : 김상우, 대구광역시 남구 대명동 317-1, 영남대학교 의과대학 신경외과학교실

Tel: (053) 620-3790, Fax: (053) 620-3770, E-Mail: sw902@ynu.ac.kr 
a dural or arachnoid tear and it is one of rare complications of lumbar disc surgery. They are encapsulated cerebrospinal fluid collections developing extradurally as a consequence of incidental dural tears. They are typically located in the paraspinal compartment and occasionally reach the subcutaneous spaces. We report a patient who had back and leg pain with pseudomeningocele after a lumbar discectomy and several revision surgery.

\section{Case Report}

A 23-year-old man had low back pain and right leg pain. Four months earlier, he had undergone surgery for herniated nucleus pulposus on L4-L5 segment and three times revision surgery for CSF leakage. Three months postoperatively, he complained a soft

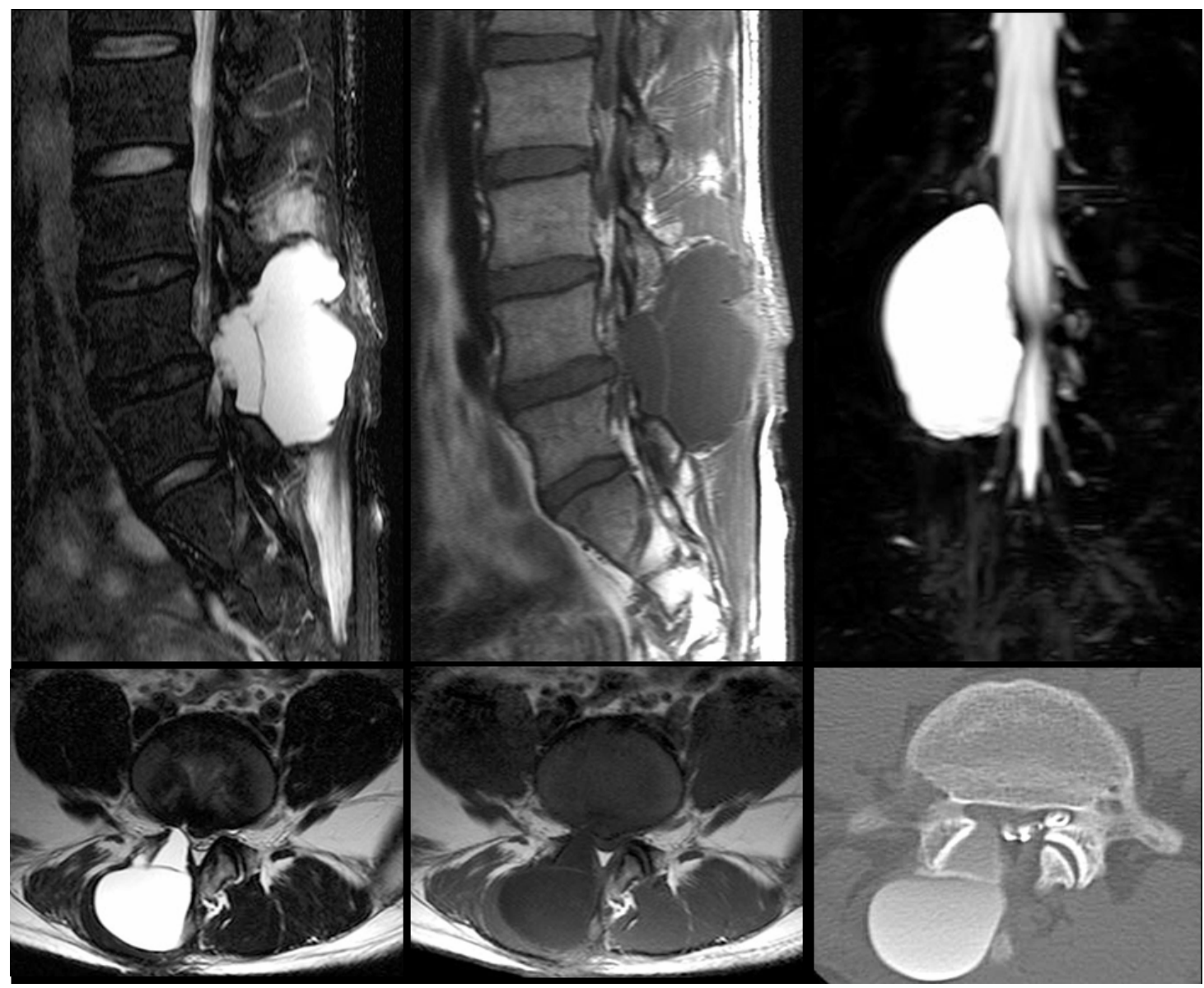

Fig. 1. MR imaging reveals a large cyst formation in the low back which communicated with laminectomy site. it demonstrates a mass with low signal intensity on T1 weighted image and high signal intensity on $\mathrm{T} 2$ weighted image. Axial computed tomography- myelogram image demonstrates the communication between the meningocele sac and the thecal sac. 
mass in the back and persistent right leg pain.

At examination, the wound was healed superficially, but there was a soft mass in the back at the site of the incision. The mass became more tense when the patient stood, and pressure applied over the mass caused intense pain and paresthesia down to the right leg.

On admission, a magnetic resonance imaging (MRI) study revealed a large cystic formation in the low back which communicated with laminectomy site and it demonstrated a mass with low signal intensity on T1 weighted image and high signal intensity on $\mathrm{T} 2$ weighted image(Fig. 1).

At surgery, the pseudomeningocele was exposed subcutaneously and explored inside without further laminectomy rather than along the outer margin of the pseudomeningocele. There was a defect in the lumbodorsal fascia through which the subcutaneous portion of the meningocele communicated with the paraspinal CSF collection. The inner lining of cyst with white, glistening wall extended along the inferior wall. A dural tear was identified just around the nerve root with some suture materials and there was persistent CSF leaks. The dura was closed with interrupted sutures. Then we performed sandwich-typed fat graft with glue.

Postoperatively, the patient had complete relief of his leg pain and the wound healed satisfactory without palpable back mass. Magnetic resonance imaging performed 2 weeks after the repair of the pseudomeningocele

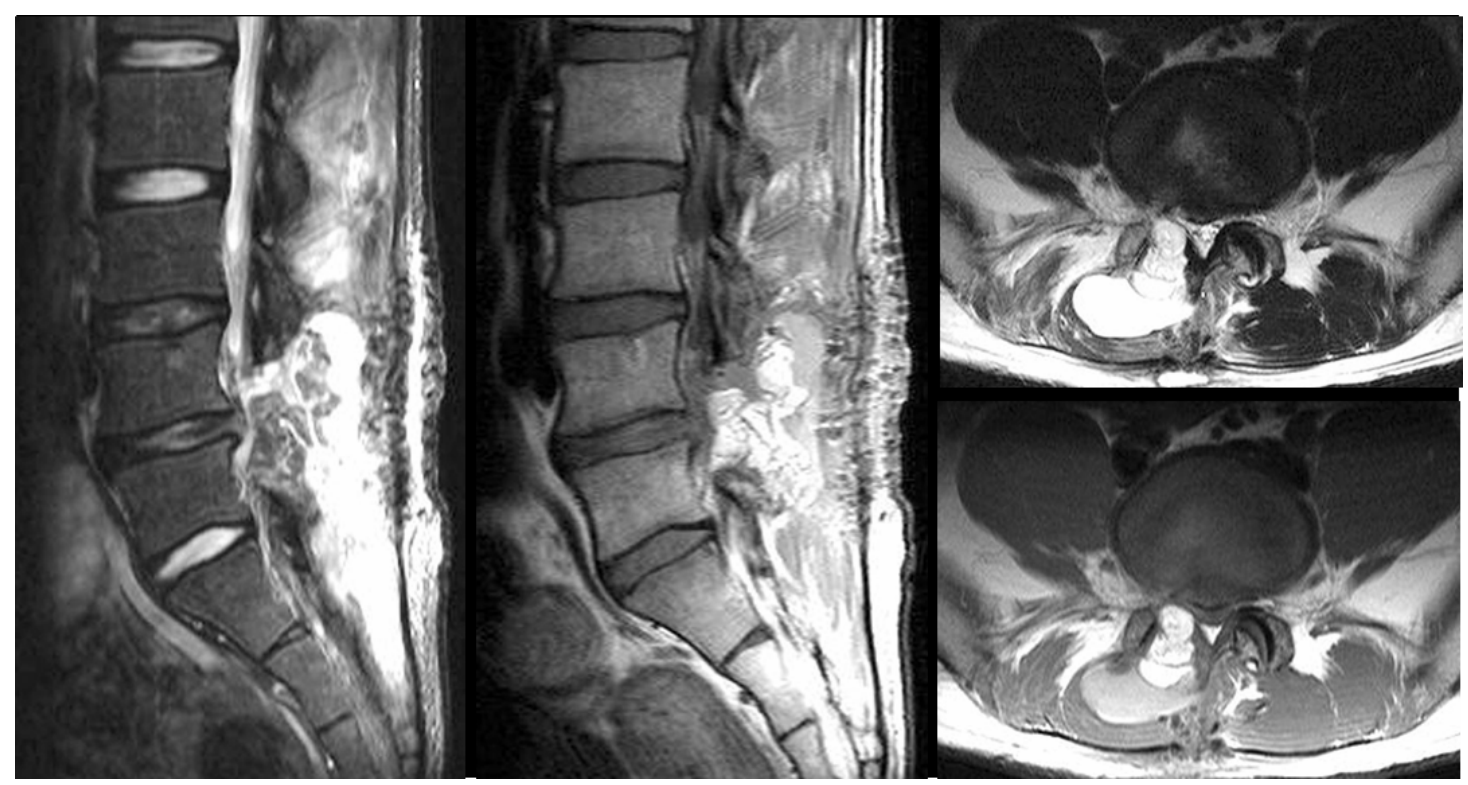

Fig. 2. Postoperative 2 weeks, MR imaging reveals grafted fat and small remnant cyst but there is no further pressure effect. 
demonstrated no recurrent CSF leakage or meningocele(Fig. 2). The patient reports no leg pain or palpable mass in the back 7 months postoperatively.

Visual analog scale(VAS) improved from a preoperative value of 5.5(leg pain), 3(back pain), to 0,1 at 17 days and 0,1 at 7 weeks and 0,0 at 7 months postoperation. The Oswestry disability index(ODI) also improved with corresponding values of $52,18,9$, and 0 .

\section{Discussion}

Incidental durotomy is one of the frequent complications during spinal surgery. The incidence of unintended durotomy during spinal surgery varies in different series between $4 \%$ and $14 \% .^{2-4)}$ In a series of 641 consecutive patients who underwent lumbar decompressive surgery, Wang et al. ${ }^{4)}$ reported 88 dural tears, a rate of $14 \%$. An analysis by Stolke et al. ${ }^{6}$ of 412 primary and 69 reoperations for herniated lumbar disc revealed a dural tear prevalence of $1.8 \%$ of microdis ${ }^{-}$ kectomies, $5.3 \%$ of the cases with macrotechnique, and $17.4 \%$ of reoperations. Other studies have shown prevalence rates of $4 \%$,3) and $5.3 \%^{1)}$ for various lumbar procedures.

Dural-cutaneous fistulas may form, leading to meningitis, ${ }^{7}$ arachnoiditis, or epidural abscess. ${ }^{8)}$ A subcutaneous fluid collection prevents proper wound healing and may lead to breakdown, infection of the incision. Continuous cerebrospinal fluid leak also predispose the wound to pseudomeningocele formation, with possible trapping of nerve roots and neurologic symptoms such as sciatica and cranial nerve palsies, particularly of cranial nerve VI, which manifests as strabismus. ${ }^{9-11)}$ A debilitating headache that arises when the patient sits upright and resolves on recumbency may occur.

A postlaminectomy pseudomeningocele was reported first 1946 by Hyndman and Gerber in a review of spinal extradural cysts. ${ }^{12)}$ In 1947, Swanson and Fincher ${ }^{13)}$ reported the first three cases of pseudomeningocele after a lumbar discectomy and noted that the symptoms of the pseudomeningocele were similar to the patients' preoperative symptoms. Pseudomeningocele, defined as extradural collections of CSF, can be found in $2 \%$ of patients undergoing lumbar laminectomies. ${ }^{14)}$

The term pseudomeningocele reflects the absence of a true meningeal layer lining the cyst wall. Instead, a reactive fibrous tissue is usually found to constitute the capsule of these lesions. $^{\text {7) }}$

The CSF flowing into tissues is resorbed for only a short period and subsequently the fluid sets up a connective tissue reaction with formation of a pseudocystic cavity. ${ }^{15)}$ If the arachnoid remains intact, there may be a herniation of the arachnoid through the dural opening resulting in a arachnoid-lined cyst. ${ }^{14}{ }^{16,17)}$ Nerve roots may herniate into the dural opening into the extraspinal sac and form a physical barrier to the healing of 
the dura. $^{16)}$

Pseudomeningoceles can be either symptomatic or not. It may be difficult to determine the relationship of symptoms to the presence of a pseudomeningocele in patients with residual or recurrent complaints after a lumbar discectomy. The symptoms of a lumbar pseudomeningocele generally are similar to the symptoms of lumbar radiculopathy, and back and leg pain are the most common symptoms. $^{13,14,18,19)}$ Radicular pain may be the result of the herniation of nerve roots into the meningocele sac or adhesions of nerve roots to the dural edges of the pseudomeningocele. ${ }^{16,20)}$ With a sudden increase of intraspinal pressure, the root or roots may be wedged against the opening, resulting in acute radicular pain. ${ }^{17)}$ Pressure over the paraspinal masses at the site of surgery may also elicit similar pain as occured in this case. If the pseudomeningocele extends through the lumbosacral fascia, there will be a palpable subcutaneous fluid collection that may enlarge with the elevation of intraspinal pressure. $^{18)}$

Although myelography will demonstrate the communication between the meningocele sac and the thecal sac, computed tomography scanning has been considered the diagnostic choice for postlaminectomy pseudomeningocele, but the entrapped root could be identified only at operation. ${ }^{14,20,21)}$

MRI can provide additional information as to the type of contents of the cyst and it shows the orientation of the pseudomeningocele to the surrounding tissues, because the actual site and size of the sac are visualized in the orthogonal planes. ${ }^{21,22)}$

The treatment of these collection of cerebrospinal fluid is somewhat controversial. Asymptomatic pseudomeningocele may be left untreated. However, it may be difficult to confirm that the pseudomeningocele is truly asymptomatic. The resolution of a pseudomeningocele has been reported after repeated aspirations or by lumbar peritoneal shunt. ${ }^{18)}$ It may be treated with combination of initial surgical drainage along with a 40cc autologous fibrin patch injected at the collection site. $^{18)}$

The definitive treatment of a postlaminectomy pseudomeningocele is surgical and requires adequate bony removal in order to expose the entire dural laceration. ${ }^{5)}$ We explored inside of the cyst without further laminectomy and removal of the pseudomeningocele without any fusion procedure in this case.

The surgical procedure should be aimed at releasing the entrapped nerve root or roots and manipulating it back into the dural sac. $^{20)}$ Midline dural tear in the spine is repaired by direct application of sutures; however, far-lateral, around the nerve root or ventral dural tears are problematic. ${ }^{23)}$ The dura should be closed primarily, if at all possible. A dural graft may be necessary, and the pseudomeningocele sac provides a readily available source of autogenous graft 
material. Fibrin glue along the suture line may be helpful particularly for lateral defect. $^{18,20)}$ The use of a fat graft is recommended as a rapid, effective means of prevention and repair of CSF leaks following spinal surgery. ${ }^{23)}$ Fibrin glue is spread on the surface of the fat and is further covered with another fat and fibrin glue as sandwich pattern.

The removal of the entire pseudocyst itself is unnecessary. ${ }^{20)}$

\section{Conclusion}

The incidence of unintended durotomy during spinal surgery varies in different series. The formation of a pseudomeningocele begins with a tear in the dura that is closed incompletely or goes unnoticed at the time of a laminectomy. When clinical suspicion exists, detection is prompt, and treatment is adequate, outcomes generally are favorable without longterm sequelae. The definitive treatment of a postlaminectomy pseudomeningocele is surgical and requires adequate bony removal in order to expose the entire dural laceration. We report a case of postlaminectomy pseudomeningocele that was successfully treated by internal exploration without further laminectomy, dural suture and sandwich fat graft.

\section{요 약}

요추부 디스크제거술후 발생한 가성수막류 를 지방이식을 통하여 성공적으로 수술적 치료 를 하였기에 문헌 고찰과 함께 보고한다. 23세 남자환자로 하부요통과 우측 하지통증을 동반 한 절개부위의 연성종괴를 주소로 내원하였다. 환자는 4 개월 전 요추 $4-5$ 번간 추간반 탈출증 으로 후궁절제술을 포함한 디스크제거수술을 받았으며 척수액 유출로 세번의 재수술을 시행 한 병력이 있었다. 자기공명촬영상 후궁절제술 부위와 교통하는 거대 낭종이 발견되었다. 수 술시 가성수막류를 박리하고 추가 후궁절제술 없이 접근하여 신경근 주위의 경막열상과 지속 되는 척수액 유출을 발견하였다. 경막봉합과 함께 지방이식을 시행하였다. 수술후 하지통증 은 완전히 사라졌으며 상처도 촉지되는 종괴 소견 없이 치유되었다.

\section{References}

1. Waisman M, Schweppe Y. Postoperative cerebrospinal fluid leakage after lumbar spine operations. Conservative treatment. Spine 1991 Jan;16(1):52-3.

2. Eismont FJ, Wiesel SW, Rothman RH. Treatment of dural tears associated with spinal surgery. J Bone Joint Surg Am 1981 Sep;63(7):1132-6.

3. Jones AA, Stambough JL, Balderston RA, Rothman RH, Booth RE, Jr. Long-term results of lumbar spine surgery complicated by unintended incidental durotomy. Spine 1989 Apr;14(4):443-6.

4. Wang JC, Bohlman $\mathrm{HH}$, Riew KD. Dural tears secondary to operations on the lumbar spine. Management and results after a twoyear-minimum follow-up of ighty-eight patients. 
J Bone Joint Surg Am 1998 Dec;80(12): 1728-32.

5. Lee KS, Hardy IM, 2nd. Postlaminectomy lumbar pseudomeningocele: report of four cases. Neurosurgery 1992 Jan;30(1):111-4.

6. Stolke D, Sollmann WP, Seifert V. Intra- and postoperative complications in lumbar disc surgery. Spine 1989 Jan;14(1):56-9.

7. Koo J, Adamson R, Wagner FC, Jr., Hrdy DB. A new cause of chronic meningitis: infected lumbar pseudomeningocele. Am J Med 1989 Jan;86(1):103-4.

8. Verner EF, Musher DM. Spinal epidural abscess. Med Clin North Am 1985 Mar;69(2):375-84.

9. Borgesen SE, Vang PS. Extradural pseudocysts. A cause of pain after lumbar-disc operation. Acta Orthop Scand 1973;44(1):12-20.

10. Nash CL, Jr., Kaufman B, Frankel VH. Postsurgical meningeal pseudocysts of the lumbar spine. Clin Orthop Relat Res 1971 Mar-Apr;75:167-78.

11. O'Connor D, Maskery N, Griffiths WE. Pseudomeningocele nerve root entrapment after lumbar discectomy. Spine 1998 Jul 1;23 (13):1501-2.

12. Hyndman OR, Gerber WF. Spinal extradural cysts, congenital and acquired. Report of cases. J Neurosurg 1946:3(6);474-486.

13. Swanson HS, Fincher EF. Extradural arachnoid cysts of traumatic origin. J Neurosurg 1947;4 (6):530-538

14. Teplick JG, Peyster RG, Teplick SK, Goodman LR, Haskin ME. CT Identification of postlaminectomy pseudomeningocele. AJR
Am J Roentgenol 1983 Jun;140(6):1203-6.

15. Pagni CA, Cassinari V, Bernasconi V. Meningocele spurius following hemilaminectomy in a case of lumbar discal hernia. J Neurosurg 1961 Sep;18:709-10.

16. Rinaldi I, Hodges TO. Iatrogenic lumbar meningocoele: report of three cases. J Neurol Neurosurg Psychiatry 1970 Aug;33(4):484-92.

17. Rinaldi I, Peach WF, Jr. Postoperative lumbar meningocele. Report of two cases. J Neurosurg 1969 Apr:30(4):504-7.

18. Barron JT. Radiologic case study. Lumbar pseudomeningocele. Orthopedics 1990 May;13 (5):603, 8-9.

19. Tsuji H, Handa N, Handa O, Tajima G, Mori K. Postlaminectomy ossified extradural pseudocyst. Case report. J Neurosurg 1990 Nov;73(5): 785-7.

20. Hadani M, Findler G, Knoler N, Tadmor R, Sahar A, Shacked I. Entrapped lumbar nerve root in pseudomeningocele after laminectomy: report of three cases. Neurosurgery 1986 Sep;19(3):405-7.

21. Schumacher HW, Wassmann H, Podlinski C. Pseudomeningocele of the lumbar spine. Surg Neurol 1988 Jan;29(1):77-8.

22. Murayama S, Numaguchi Y, Whitecloud TS, Brent CR. Magnetic resonance imaging of post-surgical pseudomeningocele. Comput Med Imaging Graph 1989 Jul-Aug;13(4):335-9.

23. Black P. Cerebrospinal fluid leaks following spinal surgery: use of fat grafts for prevention and repair. J Neurosurg. 2002 Mar;96(2 Suppl): 250-2. 